\title{
Pemanfaatan $\alpha$-Tokoferol untuk Meningkatkan Profil Superoksida Dismutase (SOD) Ginjal Tikus di Bawah Kondisi Stres
}

\section{Utilization of $\alpha$-Tocopherol to Increase Profile of Superoxide Dismutase (SOD) in the Kidney of Rats under Stress Condition}

\author{
Tutik Wresdiyati $^{*}$, Made Astawan², Diini Fithriani ${ }^{2}$ I Ketut Mudite Adnyane', Mustika \\ Hidayati $^{1}$ \\ ${ }^{1}$ Bagian Anatomi, Histologi dan Embriologi, Departemen Anatomi, Fisiologi dan Farmakologi \\ Fakultas Kedokteran Hewan, Institut Pertanian Bogor \\ E-mail: twresdiyati@yahoo.com *Penulis untuk korespondensi \\ ${ }^{2}$ Bagian Biokimia, Departemen Ilmu dan Teknologi Pangan, F. Teknologi Pertanian, Institut Pertanian Bogor
}

\begin{abstract}
Stress condition has been reported decreased the level of intracellular antioxidant, especially superoxide dismutase (SOD). The condition can lead to certain cell impairment and finally can reach to the degenerative processes, such as aging and carcinogenesis. We need several alternative treatments to solve the severe problem under antioxidant defiency status caused by stress condition. The aim of the study was to observe the effect of $\alpha$-tocopherol on increasing the profile of superoxide dismutase (SOD) in the kidney of rats under stress condition. The stress condition was achieved by five days fasting together with smimming for $5 \mathrm{~min} /$ day and only drinking distiled water ad libitum. $\alpha$-tocopherol was orally administrated at a dose of 60 $\mathrm{mg} / \mathrm{Kg} / \mathrm{BW} / \mathrm{day}$ for seven days. By measuring SOD activity and Cu,Zn-SOD imunohistochemically, showed that $\alpha$-tocopherol has effect on increasing the profile of intracellular antioxidant in the rats kidney tissue under stress condition.
\end{abstract}

Key words: $\alpha$-tocopherol, kidney, stress, superoxide dismutase, immunohistochemistry

Diterima: 30 Januari 2008, disetujui: 03 Agustus 2008

\section{Pendahuluan}

Stres adalah suatu kondisi patofisiologis yang pada akhirnya dapat mengakibatkan terjadinya penggunaan energi secara berlebihan dan terus menerus. Stres puasa merupakan suatu kondisi stres yang telah terbukti dapat menimbulkan stres oksidatif (Wresdiyati et al., 2002; Wresdiyati, 2003). Stres oksidatif adalah suatu kondisi terjadinya ketidakseimbangan antara jumlah radikal bebas dengan antioksidan dalam tubuh, dengan jumlah radikal bebas melebihi kapasitas antioksidan yang berfungsi menetralisir.

Tubuh mempunyai sistem pertahanan terhadap radikal bebas yang berupa enzim antioksidan seperti superoksida dismutase; copper zinc-superoxide dismutase $(\mathrm{Cu}, \mathrm{Zn}$ SOD) (Fridovich, 1975) dan manganese superoxide dismutase (Mn-SOD) (Marklund, 1984), katalase dan glutation peroksidase (Asayama et al., 1996). Superoksida dismutase (SOD) merupakan lini pertahanan terdepan tubuh terhadap radikal bebas. SOD mengkatalisis radikal bebas anion superoxide menjadi hidrogen peroksida dan molekul oksigen (Mates et al., 1999). Selanjutnya hidrogen peroksida dikatalis oleh katalase dan glutation peroksidase.

SOD telah berhasil dideteksi secara imunositokimia pada jaringan tikus dan manusia (Dobashi et al., 1989; Wresdiyati dan Makita, 1997). Peranan penting SOD dalam kelangsungan proses fisiologis tubuh telah 
diketahui, misal kegagalan kehamilan pada manusia karena terjadi penurunan status $\mathrm{Cu}, \mathrm{Zn}$ SOD (Sugino et al., 2000). Profil SOD juga telah dilaporkan pada kondisi patofisiologis seperti diabetes mellitus dan hiperkolesterolemia (Wresdiyati et al., 2003; Wresdiyati et al., 2006), pada jaringan neoplastik (Keller et al., 1991), serta pada neuron hipokampus penderita Alzheimer dan Down's syndrome (Furuta et al., 1995).

Wresdiyati et al., (2002) dan Wresdiyati (2003) melaporkan bahwa kondisi stres pada tikus menurunkan kandungan antioksidan intrasel copper, zinc-superoksida dismutase (Cu,Zn-SOD) pada jaringan hati dan ginjal. Kondisi menurunnya status antioksidan intrasel sangat berbahaya karena radikal bebas dalam tubuh tidak ternetralisir dengan baik, yang dalam kurun waktu tertentu jumlahnya dapat meningkat dan berlebih. Radikal bebas dalam jumlah yang berlebihan dapat merusak makromolekul komponen sel seperti karbohidrat, protein, DNA dan sebagainya. Kerusakan ini dapat berakhir pada kematian sel (Halliwel dan Gutteridge, 1999). Sehingga upaya penanganan terhadap menurunnya status antioksidan perlu dilakukan, terutama pada kondisi stres.

Penelitian ini merupakan salah satu upaya pemanfaatan $\alpha$-tokoferol dalam mengatasi penurunan antioksidan intrasel-SOD pada kondisi stres. Penelitian ini bertujuan untuk memanfaatkan $\alpha$-tokoferol dalam meningkatkan profil antioksidan intrasel SOD pada kondisi stres. Pengamatan dilakukan terhadap aktivitas SOD dan kandungan $\mathrm{Cu}, \mathrm{Zn}$ SOD pada jaringan ginjal tikus. Sehingga $\alpha$ tokoferol diharapkan dapat dipakai sebagai bahan alternatif pencegahan maupun pengobatan terhadap menurunnya status SOD akibat stres.

\section{Metode Penelitian}

\section{Hewan percobaan dan perlakuan}

Dua puluh lima ekor tikus jantan galur Wistar $(250 \pm 5 \mathrm{~g})$ digunakan pada penelitian ini. Tikus dikelompokkan menjadi 5 kelompok perlakuan (5 ekor per kelompok) (Tabel 1). Kondisi stres dilakukan dengan cara puasa (tidak diberikan pakan), tetapi diberi air minum ad libitum serta perenangan dalam air 5 menit/hari selama 5 hari. Diluar perlakuan stres tikus diberi pakan ad libitum. Alfa tokoferol diberikan per oral menggunakan sonde dengan dosis $60 \mathrm{mg} / \mathrm{Kg} / \mathrm{BB} /$ hari, dilarutkan pada minyak jagung. Di akhir perlakuan, hewan percobaan dikorbankan dan jaringan ginjalnya diambil. Jaringan ginjal kemudian dibagi dua untuk dilakukan analisis terhadap (1) aktivitas SOD, dan (2) kandungan $\mathrm{Cu}, \mathrm{Zn}-\mathrm{SOD}$ secara imunohistokimia.

\section{Analisis aktivitas SOD ginjal tikus (Chen et al., 1996)}

\section{Persiapan larutan standar}

Larutan standar dibuat dengan melarutkan SOD murni komersial menjadi beberapa konsentrasi larutan, yaitu 10, 25, 50, 250, 500 units $/ \mathrm{ml} \mathrm{H}_{2} \mathrm{O}$ dan digunakan untuk membuat kurva baku/standar.

\section{Persiapan sampel}

Potongan ginjal diblender halus, kemudian ditambah dengan buffer phosphat $\mathrm{pH}$ 7.4 dengan perbandingan $1: 0.5$, kemudian disentrifuse pada kecepatan $10000 \mathrm{rpm}$ selama 20 menit dan diambil bagian cairannya (lisat). Lisat ginjal dengan segera disimpan pada suhu $-20^{\circ} \mathrm{C}$. Sebanyak $400 \mu \mathrm{l}$ larutan kloform/etanol dingin 37,5/62,5 (v/v) ditambahkan ke dalam $150 \mu \mathrm{l}$ lisat ginjal. Kemudian divorteks selama 3 detik dan disentrifus pada kecepatan 4400 rpm suhu $4^{\circ} \mathrm{C}$ selama 10 menit. Selanjutnya supernatan disimpan pada suhu antara $2-8^{\circ} \mathrm{C}$ dan siap untuk dianalisis.

\section{Pengukuran aktivitas SOD}

Aktivitas SOD diuji berdasarkan laju penghambatan reduksi ferrisitokrom $\mathrm{c}$ oleh anion superoksida yang dihasilkan oleh xantin/xantin oksidase. Terjadi oksidasi xantin menjadi asam urat dan anion superoksida yang terbentuk selanjutnya mereduksi ferrisitokrom c. Reduksi ferrisitokrom c diamati berdasarkan kenaikan absorbansi. Pengukuran aktivitas enzim ini berlangsung dengan memasukkan 2,9 ml larutan A (campuran larutan xantin dan larutan sitokrom c) ke dalam tabung reaksi 3 ml. Selanjutnya ditambah $50 \mu$ larutan b 
(xantin oksidase) dan divorteks secara perlahan. Perubahan absorban yang terjadi diukur dengan spektrofotometer pada panjang gelombang $550 \mathrm{~nm}$. Untuk blanko digunakan buffer fosfat sebagai pengganti sampel.

\section{Pemrosesan jaringan dan pewarnaan imunohistokimia}

Setelah jaringan ginjal diambil difiksasi dalam larutan Bouin selama 24 jam, diikuti dengan proses dehidrasi menggunakan alkohol bertingkat dan penjernihan dengan silol sebelum dilakukan embedding dalam parafin. Blok jaringan dipotong setebal $4 \mu \mathrm{m}$. Setelah dilakukan deparafinisasi dan rehidrasi, potongan jaringan diwarnai secara imunohistokimia terhadap $\mathrm{Cu}, \mathrm{Zn}-\mathrm{SOD}$ menggunakan metode Dobashi et al., (1989) dengan sedikit modifikasi pada jenis antibodi sekunder. Pada penelitian ini digunakan antibodi sekunder dako polimer peroksidase (Dako K1491). Setelah dilakukan deparafinisasi dan rehidrasi, potongan jaringan diberi perlakuan $\mathrm{H}_{2} \mathrm{O}_{2} 3 \%$ (10 menit) untuk inaktivasi peroksidase endogen. Kemudian potongan jaringan diinkubasi dalam serum normal $10 \%$ (30 menit) pada suhu $37^{\circ} \mathrm{C}$. Potongan jaringan selanjutnya dicuci dengan bufer fosfat sebelum diinkubasi dalam antibodi primer, yaitu antibodi monoklonal $\mathrm{Cu}, \mathrm{Zn}-\mathrm{SOD}$ (Sigma S2147) pada suhu $4^{\circ} \mathrm{C}$. Potongan jaringan diinkubasi lagi dalam antibodi sekunder yang telah dilabel polimer peroksidase (Dako K1491) pada suhu $37^{\circ} \mathrm{C}$. Produk reaksi antigen-antibodi dalam potongan jaringan divisualisasi dengan diamino benzidine (DAB) selama 25 menit pada suhu ruang. Selanjutnya dilakukan dehidrasi dengan alkohol bertingkat dan penjernihan dengan silol, serta penutupan potongan jaringan dengan kaca penutup menggunakan perekat. Sebagai kontrol, digunakan potongan jaringan yang diinkubasi menggunakan bufer fosfat sebagai pengganti antibodi monoklonal $\mathrm{Cu}, \mathrm{Zn}$ SOD.

Pengamatan terhadap sel-sel penghasil $\mathrm{Cu}, \mathrm{Zn}-\mathrm{SOD}$ dilakukan dengan dua cara, yaitu pengamatan kualitatif dan kuantitatif. Pengamatan kualitatif dilakukan terhadap produk reaksi positif pada glomerulus, tubuli renalis distalis, tubuli renalis proksimalis, dan daerah medula. Pengamatan terhadap sel-sel penghasil $\mathrm{Cu}, \mathrm{Zn}-\mathrm{SOD}$ secara kuantitatif dilakukan dengan cara menghitung inti sel tubuli renalis berdasarkan intensitas warna cokelat yang terbentuk. Intensitas warna cokelat tersebut menunjukkan kandungan $\mathrm{Cu}, \mathrm{Zn}$-SOD, semakin tua warna dan merata produk reaksi berarti semakin banyak kandungan $\mathrm{Cu}, \mathrm{Zn}$-SODnya. Pengamatan kuantitatif dilakukan terhadap inti sel tubuli renalis yang memberikan reaksi positif pada berbagai tingkat kandungan terhadap $\mathrm{Cu}, \mathrm{Zn}$ SOD (coklat tua atau positif kuat/+++, coklat sedang atau positif sedang/++, dan coklat muda campur biru atau positif lemah/ + dan warna biru atau negatif/-). Penghitungan inti sel dilakukan per bidang pandang pada pembesaran $400 x$, dilakukan 5 acak pada setiap preparat jaringan.

Tabel 1. Kelompok perlakuan tikus percobaan dan jenis perlakuan.

\begin{tabular}{|c|c|c|c|}
\hline \multirow[b]{2}{*}{ Kelompok } & \multicolumn{3}{|c|}{ Perlakuan } \\
\hline & $\begin{array}{c}\alpha \text {-tokoferol (7 hari) } \\
60 \mathrm{mg} / \mathrm{Kg} / \mathrm{BB} / \text { hari }\end{array}$ & Stres (5 hari)* & $\begin{array}{c}\alpha \text {-tokoferol (7 hari) } \\
60 \mathrm{mg} / \mathrm{Kg} / \mathrm{BB} / \mathrm{hari}\end{array}$ \\
\hline Kontrol & - & 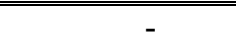 & - \\
\hline $\mathrm{S}$ & - & + & - \\
\hline AS & + & + & - \\
\hline SA & - & + & + \\
\hline ASA & + & + & + \\
\hline $\begin{array}{l}\text { Keterangan: } \\
+ \text { : diberi perlakuan } \\
- \text { : tanpa perlakuan } \\
* \text { : puasa } 5 \text { hari dan }\end{array}$ & a menit/hari & ferol & \\
\hline
\end{tabular}




\section{Analisis data}

Hasil pengukuran aktivitas SOD, dan jumlah inti sel tubuli renalis pada berbagai tingkat kandungan $\mathrm{Cu}, \mathrm{Zn}-\mathrm{SOD}$ ginjal tikus perlakuan masing-masing disusun sebagai Rancangan Acak Lengkap (RAL) dan dianalisis dengan Analisis Sidik Ragam (Anova). Apabila terdapat perbedaan yang nyata dilanjutkan dengan uji beda Duncan (Steel dan Torrie, 1986).

\section{Hasil dan Pembahasan}

\section{Aktivitas superoksida dismutase pada ginjal}

Analisis aktivitas superoksida dismutase (SOD) pada ginjal tikus perlakuan menunjukan bahwa kelompok stres (S) memiliki aktivitas SOD terendah yaitu sebesar $1174.40 \mathrm{U} / \mathrm{g}$ dan diikuti oleh kelompok stres- $\alpha$-tokoferol (SA) sebesar $3174.55 \mathrm{U} / \mathrm{g}$, kelompok $\alpha$-tokoferolstres (AS) sebesar $3743.40 \mathrm{U} / \mathrm{g}$, dan kelompok kontrol sebesar $4165.45 \mathrm{U} / \mathrm{g}$. Sedangkan pada kelompok $\alpha$-tokoferol-stres- $\alpha$-tokoferol (ASA) menunjukkan aktivitas SOD paling tinggi yaitu sebesar $4238.85 \mathrm{U} / \mathrm{g}$ (Gambar 1).

Uji statistik lanjutan menggunakan uji Duncan $\alpha=0.05$ menunjukkan, aktivitas antioksidan SOD antara kelompok kontrol, AS, SA, dan ASA, tidak ada perbedaan yang nyata.
Aktivitas antioksidan SOD kelompok S berbeda nyata dengan kelompok $\mathrm{K}, \mathrm{AS}, \mathrm{SA}$, ASA $(\mathrm{p}<0.05)$ (Gambar 1). Hasil tersebut menunjukkan bahwa perlakuan pemberian $\alpha$ tokoferol memberikan pengaruh yang nyata terhadap aktivitas SOD. Pemberian $\alpha$-tokoferol baik secara preventif (AS), kuratif (SA) ataupun kombinasi keduanya (ASA) memberikan pengaruh yang sama terhadap aktivitas SOD, yaitu dapat mempertahankan aktivitas SOD sehingga tidak berbeda nyata dengan kelompok kontrol, pada jaringan ginjal tikus.

Aktivitas SOD pada kelompok stres terlihat paling rendah. Hal ini menunjukkan pada kondisi stres radikal bebas terbentuk dalam jumlah berlebih sehingga banyak SOD diperlukan untuk menetralkan radikal bebas tersebut, akibatnya aktivitas SODnya jauh lebih rendah dan berbeda nyata dengan kelompok kontrol. Sedangkan pemberian $\alpha$-tokoferol berpengaruh nyata dalam mempertahankan aktivitas SOD pada kondisi stres baik secara preventif (AS), kuratif (SA) ataupun kombinasi keduanya (ASA). Hal ini menunjukkan peranan $\alpha$-tokoferol dalam memerangi radikal bebas yang terbentuk berlebihan pada kondisi stres. Aktivitas antioksidan dari $\alpha$-tokoferol tersebut sangat membantu antioksidan endogen, sehingga aktivitas SOD dapat dipertahankan pada kondisi stres.

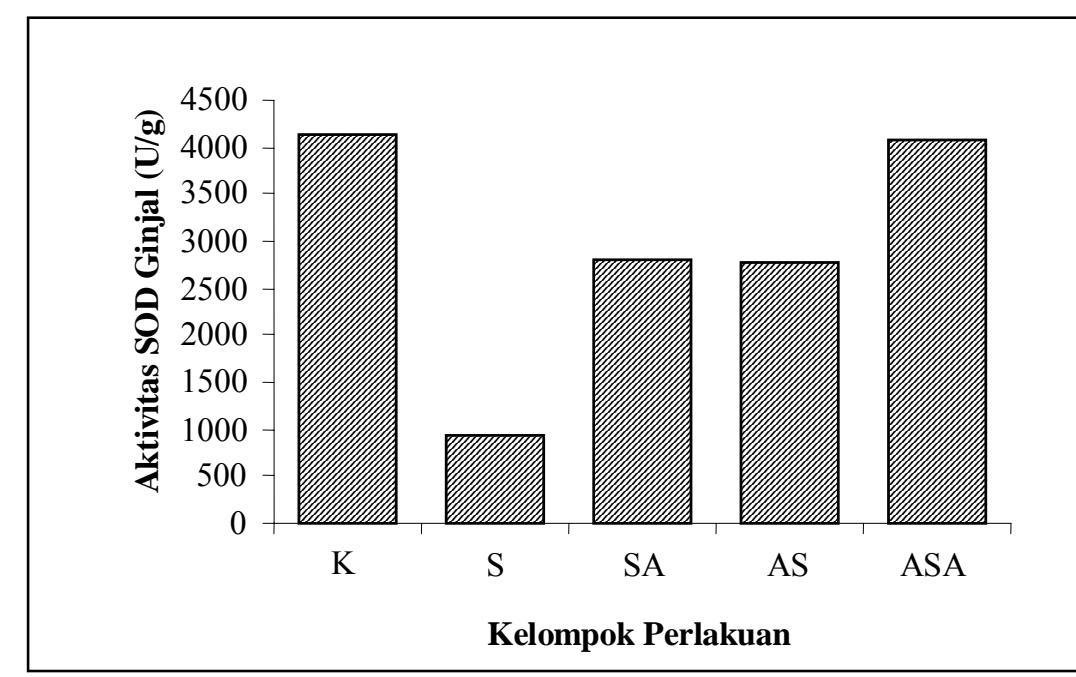

\footnotetext{
Gambar 1. Aktivitas SOD (U/g) ginjal tikus perlakuan.

Keterangan: $\mathrm{K}=$ kontrol

$\mathrm{S}=$ stres

$\mathrm{SA}=$ stres $+\alpha$-tokoferol
} 
Sebagai senyawa fenolik, tokoferol $\left(\mathrm{AH}_{2}\right)$ mampu menangkal radikal bebas dan radikal lemak $\left(\mathrm{R}^{\bullet}\right)$, sehingga menghasilkan kembali molekul $\mathrm{RH}$ dan juga memproduksi radikal tokoferil semiquinone $\left(\mathrm{AH}^{\bullet}\right)$ (Gambar 2). Dua buah radikal tokoferil semiquinone dapat membentuk tokoferil quinone $\left(\mathrm{A}^{\bullet}\right)$ dan menghasilkan kembali molekul tokoferol melalui reaksi berikut:

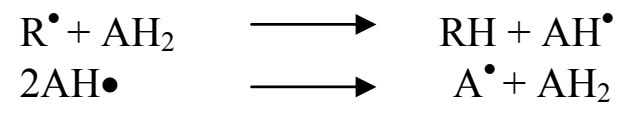

Radikal $\alpha$-tokoferil quinone setelah melepaskan satu atom $\mathrm{H}$, maka ia melepaskan kembali atom $\mathrm{H}$ lain sehingga terbentuk metil tokoferil quinone. Metil tokoferil quinone bersifat tidak stabil dan menyebabkan munculnya $\alpha$-tokoferil quinone sebagai produk utama yang stabil (Schuler, 1990).

\section{Profil antioksidan Cu,Zn-SOD}

Keberadaan dan kandungan antioksidan $\mathrm{Cu}, \mathrm{Zn}-\mathrm{SOD}$ pada jaringan ginjal tikus perlakuan terdeteksi secara imunohistokimia berupa produk reaksi yang berwarna coklat. Intensitas dan distribusi warna coklat menunjukkan kandungan $\mathrm{Cu}, \mathrm{Zn}-\mathrm{SOD}$ pada jaringan tersebut, semakin tua warna coklat dan semakin meratanya warna coklat tersebut pada jaringan berarti kandungan $\mathrm{Cu}, \mathrm{Zn}-\mathrm{SOD}$ semakin banyak. $\mathrm{Cu}, \mathrm{Zn}$-SOD terdapat pada glomerulus, inti dan sitoplasma sel tubuli proksimalis dan tubuli distalis, serta pada bagian medula. Secara kualitatif terlihat profil kandungan $\mathrm{Cu}, \mathrm{Zn}-\mathrm{SOD}$ pada kelompok stres (S) paling rendah dibanding kelompok kontrol dan kelompok perlakuan lainnya. Sedangkan kelompok perlakuan AS dan SA menunjukkan kandungan $\mathrm{Cu}, \mathrm{Zn}-\mathrm{SOD}$ yang lebih tinggi dibandingkan kelompok stres, meskipun masih lebih rendah bila dibandingkan dengan kelompok kontrol. Kandungan $\mathrm{Cu}, \mathrm{Zn}-\mathrm{SOD}$ pada kelompok ASA terlihat paling tinggi dibandingkan kelompok perlakuan AS maupun SA, bahkan sudah hampir menyamai kandungan $\mathrm{Cu}, \mathrm{Zn}-\mathrm{SOD}$ kelompok kontrol (Tabel 2 dan Gambar 3).

Distribusi dan frekuensi kandungan $\mathrm{Cu}, \mathrm{Zn}-\mathrm{SOD}$ pada jaringan ginjal tikus kelompok kontrol dan kelompok perlakuan yang dideteksi secara imunohistokimia terlihat pada sel tubuli proksimalis dan tubuli distalis, daerah medula, serta sedikit pada glomerulus (Tabel 2).

Pada kelompok Stres (S) produk hasil reaksi dari enzim terlihat lebih sedikit dibandingkan dengan kelompok Kontrol (K) (Tabel 2). Penurunan kandungan $\mathrm{Cu}, \mathrm{Zn}-\mathrm{SOD}$ pada kelompok Stres (S) terlihat nyata pada sel tubuli proksimalis dibandingkan pada sel tubuli distalis jaringan ginjal tikus (Gambar 2).

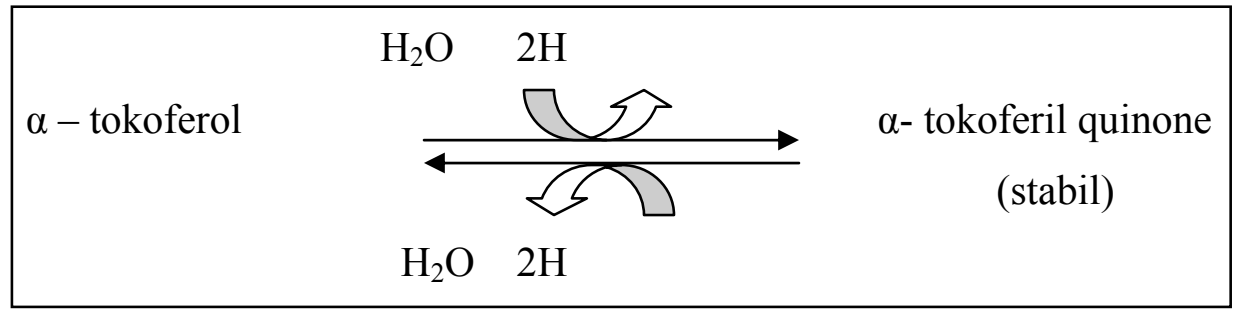

Gambar 2. Alfa tokoferol dan alfa tokoferil quinone sistem redox (Schuler, 1990).

Tabel 2. Distribusi dan frekuensi kandungan $\mathrm{Cu}, \mathrm{Zn}-\mathrm{SOD}$ pada jaringan ginjal tikus.

\begin{tabular}{ccccc}
\hline \hline \multirow{2}{*}{ Kelompok } & \multicolumn{3}{c}{ Distribusi dan Frekuensi Cu,Zn-SOD } & \multirow{2}{*}{ Medulla } \\
\cline { 2 - 4 } & Glomerulus & T. Distalis & T. Proximalis & \\
\cline { 2 - 4 } & + & ++++ & +++ & ++ \\
K & $+/$ & ++ & + & + \\
S & ++ & +++ & ++ & ++ \\
SA & ++ & +++ & ++ & ++ \\
AS & ++ & ++++ & +++ & ++ \\
ASA & & &
\end{tabular}




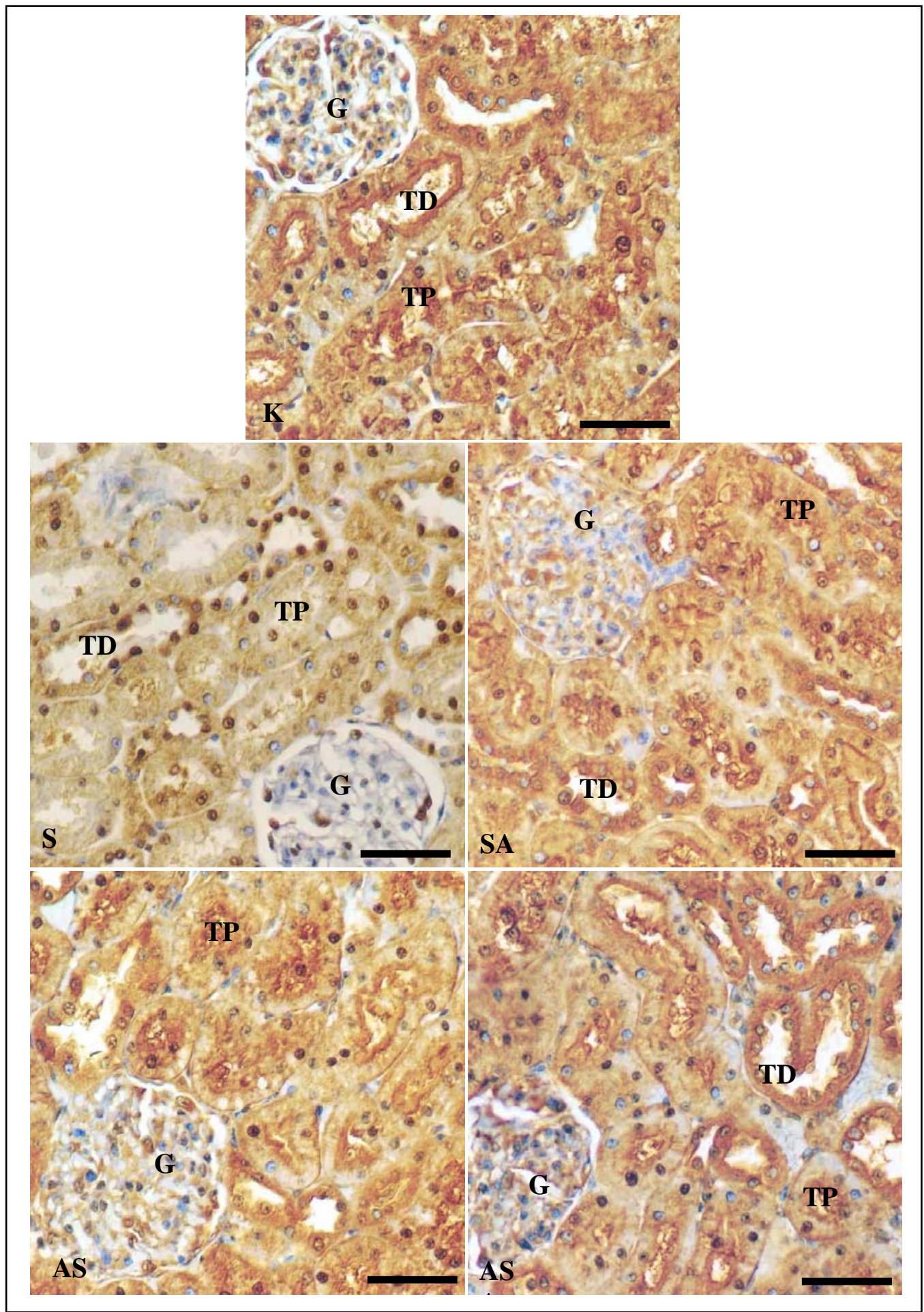

Gambar 3. Fotomikrograf jaringan ginjal tikus perlakuan yang diwarnai secara imunohistokimia terhadap $\mathrm{Cu}, \mathrm{Zn}-\mathrm{SOD}$.

Keterangan: $\mathrm{G}=$ glomerulus

$\mathrm{TP}=$ tubuli proksimalis

$\mathrm{TD}=$ tubuli distalis

$\mathrm{K}=$ control

Skala $=25 \mu \mathrm{m}$
$\mathrm{S}=$ stress

$\mathrm{SA}=$ stress- $\alpha$-tokoferol

$\mathrm{AS}=\alpha$-tokoferol-stress

ASA $=\alpha$-tokoferol-stress- $\alpha$-tokoferol 
Pada kelompok yang diberi perlakuan $\alpha$ tokoferol baik sesudah stres (SA), sebelum stres (AS), maupun kombinasi keduanya sebelum dan sesudah stres (ASA) terlihat mengalami peningkatan kandungan $\mathrm{Cu}, \mathrm{Zn}$ SOD dibandingkan dengan kelompok Stres (S). Kelompok yang diberi perlakuan $\alpha$-tokoferol secara kombinasi sebelum dan sesudah stres (ASA) menghasilkan peningkatan kandungan $\mathrm{Cu}, \mathrm{Zn}$-SOD paling tinggi dibandingkan dengan kelompok yang diberi perlakuan $\alpha$-tokoferol baik sebelum stres (AS) maupun sesudah stres (SA).

Berdasarkan hasil perhitungan secara kuantitatif yaitu dengan menghitung jumlah inti sel tubuli renalis pada berbagai tingkat kandungan $\mathrm{Cu}, \mathrm{Zn}-\mathrm{SOD}$, juga terlihat adanya penurunan kandungan $\mathrm{Cu}, \mathrm{Zn}-\mathrm{SOD}$ secara nyata $(\mathrm{p}<0.05)$ pada kelompok $\mathrm{S}$ dibandingkan kelompok K (Tabel 3). Hal ini terlihat dari menurunnya jumlah inti sel tubuli renalis yang bereaksi positif kuat, positif sedang, dan positif lemah, serta meningkatnya jumlah inti sel yang bereaksi negatif secara nyata $(\mathrm{P}<0.05)$. Hasil perhitungan dan analisa statistik terhadap ratarata jumlah inti sel tubuli renalis pada berbagai tingkat kandungan $\mathrm{Cu}, \mathrm{Zn}-\mathrm{SOD}$ tersaji pada Tabel 3.

Kandungan $\mathrm{Cu}, \mathrm{Zn}$-SOD pada kelompok yang diberi perlakuan $\alpha$-tokoferol baik sesudah stres, sebelum stres, maupun kombinasi keduanya sebelum dan sesudah stres terjadi peningkatan kandungan $\mathrm{Cu}, \mathrm{Zn}$-SOD secara nyata dibandingkan dengan kelompok Stres. Peningkatan tersebut terlihat dari peningkatan jumlah inti sel tubuli renalis pada sel positif kuat, positif sedang, dan positif lemah. Peningkatan tersebut juga terlihat dari penurunan jumlah inti sel tubuli renalis pada yang bereaksi negatif. Peningkatan kandungan $\mathrm{Cu}, \mathrm{Zn}-\mathrm{SOD}$ pada ketiga kelompok yang diberi $\alpha$-tokoferol tersebut menunjukkan tidak berbeda nyata baik diberikan sebelum, sesudah, maupun kombinasi keduanya. Peningkatan kandungan $\mathrm{Cu}, \mathrm{Zn}$-SOD pada ketiga kelompok yang diberi $\alpha$-tokoferol tersebut juga belum menyamai kandungan $\mathrm{Cu}, \mathrm{Zn}-\mathrm{SOD}$ kelompok kontrol (Tabel 3 dan Gambar 2).

Pada keadaan normal, katabolisme asam lemak terjadi di dalam mitokondria melalui proses yang dikenal sebagai ß-oksidasi. Namun dalam kondisi kelaparan terjadi peningkatan proses $\beta$-oksidasi pada peroksisom yang pada kondisi normal merupakan jalur minor proses ß-oksidasi (Orelana et al., 1992). Wresdiyati dan Makita (1995) melaporkan kondisi stres puasa menyebabkan peningkatan jumlah peroksisom yang berdampak pada peningkatan oksidasi di peroksisom. Semakin meningkatnya ß-oksidasi di dalam peroksisom dapat meningkatkan jumlah radikal bebas, yang merupakan salah satu hasil samping metabolisme.

Radikal bebas secara fisiologis selalu dihasilkan di dalam tubuh dan diperlukan untuk kelangsungan proses-proses fisiologis penting lainnya yang terjadi di dalam tubuh, seperti transport elektron. Sebagian radikal bebas yang tidak terpakai dan tersisa di dalam tubuh akan dinetralkan menjadi produk yang lebih stabil oleh enzim antioksidan intraseluler seperti superoksida dismutase, katalase, dan glutathion peroksidase. Peningkatan jumlah radikal bebas yang terus-menerus pada kondisi stres puasa akan meningkatkan pemakaian enzim antioksidan intraseluler. Sehingga status antioksidan tubuh menurun seperti yang terlihat pada jaringan ginjal tikus kelompok stres, dimana baik aktivitas SOD maupun kandungan antioksidan CU,Zn-SOD jauh lebih rendah dibandingkan pada kelompok kontrol.

Pada kelompok yang diberi $\alpha$-tokoferol sebelum stres, sesudah stres ataupun kombinasi keduanya pada jaringan ginjal menunjukkan tingginya aktivitas SOD yang secara statistik tidak berbeda $(\mathrm{P}<0.05)$ dengan kelompok kontrol, dan peningkatan kandungan $\mathrm{Cu}, \mathrm{Zn}$ SOD dibandingkan kelompok stres, meskipun belum menyamai kandungan $\mathrm{Cu}, \mathrm{Zn}-\mathrm{SOD}$ kelompok kontrol. Hal ini menunjukkan bahwa $\alpha$-tokoferol dapat diberikan baik sebagai tindakan preventif, kuratif, atau kombinasi keduanya. Hal tersebut juga menjelaskan bahwa $\alpha$-tokoferol dapat diretensi di dalam sel tubuli renalis ginjal.

Peningkatan aktivitas SOD dan kandungan antioksidan $\mathrm{Cu}, \mathrm{Zn}-\mathrm{SOD}$ pada kelompok yang diberi perlakuan stres (AS, SA, dan ASA) disebabkan oleh $\alpha$-tokoferol yang berfungsi sebagai antioksidan, yang bereaksi dengan radikal bebas membentuk produk yang 
lebih stabil, dengan cara mendonorkan ion hidrogen bagi radikal bebas sehingga radikal bebas menjadi molekul yang lebih stabil. Hal ini membuat SOD lebih ringan dalam mengkatalis reaksi dismutase radikal superoksida menjadi produk lain yang lebih stabil, sehingga kadar dalam sel tubuli renalis ginjal tikus pada penelitian ini menjadi lebih terjaga (Noguchi dan Niki, 1998).

Tabel 3. Profil Kandungan $\mathrm{Cu}, \mathrm{Zn}-\mathrm{SOD}$ pada jaringan ginjal tikus perlakuan.

\begin{tabular}{ccccc}
\hline \multirow{2}{*}{ Kelompok } & \multicolumn{4}{c}{ Jumlah inti sel tubuli renalis pada berbagai tingkat kandungan Cu,Zn-SOD } \\
perlapang pandang pada pembesaran 400x
\end{tabular}

$\overline{\text { Keterangan: superscript yang berbeda pada kolom yang sama menunjukkan nilai yang berbeda nyata }(\mathrm{p}<0.05)}$ $+++=$ positif kuat; $++=$ positif sedang; $+=$ positif lemah; $-=$ negatif.

\section{Kesimpulan}

Dari hasil penelitian dapat disimpulkan bahwa $\alpha$-tokoferol dapat digunakan sebagai alternatif lain dari oleoresin jahe untuk mengatasi kelainan antioksidan intrasel superoksida dismutase pada kondisi stres. Pemberian $\alpha$-tokoferol dapat dilakukan sebelum stres, sesudah stres, atau kombinasi keduanya.

\section{Ucapan Terima Kasih}

Penulis mengucapkan terima kasih kepada Proyek Pengkajian dan Penelitian Ilmu Pengetahuan Terapan - Direktorat Pembinaan Penelitian dan Pengabdian Pada Masyarakat, Direktorat Jendral Pendidikan Tinggi, Departemen Pendidikan Nasional yang telah mendanai sebagian penelitian ini melalui Dana Penelitian Hibah Bersaing X No. 103/LII/ BPPK-SDM/IV/2002.

\section{Daftar Pustaka}

Asayama, K., Dobashi, K., Kawada, Y., Nakane, T., Kawaoi, A. and Nakazawa, S. 1996. Immunohistochemical localization and quantitative analysis of cellular glutathione peroxidase in fetal and neonatal rat tissues: fluorescence microscopy image analysis. $J$. Histochem 28 (1): 63-71.
Chen, H.M., Muramoto, K. and Yamauchi, F. 1996. Structural Analysis of Antioxidative Peptides from Soybean $\beta$-Conglicinin. J. Agria. Food Chem. 43: 574-578.

Dobashi, K., Asayama, K., Kato, K., Kobayashi, M. and Kawaoi, A. 1989. Immuohistochemical localization and quantitative analysis of superoxide dismutase in rat tissue. Acta Histochem. Cytochem. 22: 351-365.

Fridovich, I. 1975. Superoxide dismutases. Ann. Rev. Biochem. 44: 147-159.

Furuta, A., Price, D.L., Pardo, C.A., Troncoso, J.C., Xu, Z.S., Taniguchi, N. and Martin, L.J. 1995. Localization of superoxide dismutase in Alzheimer's disease and Down's syndrome neocortex and hippocampus. J. Am. Pathol. 146 (2): 357-367.

Keller, G.A., Warner, T.G., Steimer, K.S. and Halliwell, R.A. 1991. $\mathrm{Cu}, \mathrm{Zn}$-superoxide dismutase is a peroxisomal enzyme in human fibroblasts and hepatoma cells. Proc. Natl. Acad. Sci. USA. 88: 7381-7385.

Halliwell, B. and Guttridge, J.M.C. 1999. Free radicals in biology and medicine. Clarendon Press. Oxford.

Marklund, S.L. 1984. Extracellular superoxide dismutase and other superoxide dismutase isoenzymes in tissues from nine mammalian species. $J$. Biochem. 222: 649-655.

Mates, J.M., Gomez, C.P. and Castro, I.N. 1999. Antioxidant enzymes and human diseases. Clin. Biochem. 32 (8): 595-603. 


\section{Wresdiyati et al.,}

Noguchi and Niki, E. 1998. Chemistry of Active Oxygen Species and Antioxidant dalam Antioxidant Status, Diet, Nutrition and Health. CRC Press: Boca Raton.

Orellana, M., Fuentes, O., Rosenbluth, H., Lara, M. and Valdes, F. 1992. Modulatios of rats liver peroxisomal and microsomal fatty acids oxidation by starvation. FEBS 310: 193-196.

Schuler, P. 1990. Natural antioxidantseexploitedcommercially. In: Hudson, B.J.F. (Eds.). Food Antioxidants. pp.99-170. Elsevier Applied Science. London.

Steel, R.D.G. and Torrie, J.H. 1986. Priciples and procedures of Statistics, A Biomedical Approach. McGraw-Hill Book Company, Singapore.

Sugino, N., Nakata, M., Kashida, S., Karube, A., Takiguchi, S. and Kato, H. 2000. Decreased superoxide dismutase expression and increased concentrations of lipid peroxide and prostaglandin $F 2 \alpha$ in the decidua of failed pregnancy. Mol. Human Reprod. 6 (7): 642647.

Wresdiyati, T. 2003. Imunohistochemical Study of Oxygen-Free Radical Scavenger-Copper, Zinc-Superoxide Dismutase (Cu,Zn-SOD) in The Rats Liver Under Stress Condition. Biota 8 (3): 107-112.

Wresdiyati, T. and Makita, T. 1995. Remarkable increase of peroxisomes in the renal tubule cells of Japanese monkeys under fasting stress. Pathophysiol 2: 177-182.
Wresdiyati, T. and Makita, T. 1997. Immunocytochemical localization of $\mathrm{Cu}, \mathrm{Zn}$-SOD (Cooper, zincsuperoxide dismutase) in the renal tubules and glomerulus of rat kidney. Mol. Biol. of Cell. 8: 342.

Wresdiyati, T., Mamba, K., Adnyane, I.K.M. and Aisyah, U.S. 2002. The effect of stress condition on the intracellular antioxidant copper, zincsuperoxide dismutase in the rat kidney: an immunohistochemical study. Hayati 9 (3): 8588.

Wresdiyati, T., Lelana, R.P.A., Adnyane, I.K.M. dan Noor, K. 2003. Immunohistochemical study of superoxide dismutase (SOD) in the liver of diabetic experiment Macaca fascicularis. Hayati 10 (2): 61-65.

Wresdiyati, T., Astawan, M., Adnyane, I.K.M. dan Prasetyawati, RC. 2005. Pemanfaatan Oleoresin Jahe (Zingiber officinale) untuk Mengatasi Kelainan Antioksidan Intrasel Superoxide Dismutase (SOD) Hati Tikus di bawah Kondisi Stres. Biota X (2): 120-128.

Wresdiyati, T., Astawan, M. dan Hastanti, L.Y. 2006. Profil imunohistokimia antioksidan superoksida dismutase (SOD) pada jaringan hati tikus di bawah kondisi hiperkolesterolemia. Hayati 13 (3): 85-89. 